\title{
Non-competitive ELISA with broad specificity for microcystins and nodularins
}

\author{
Sultana Akter, ${ }^{*}$ Markus Vehniäinen, ${ }^{1}$ Jussi Meriluoto, ${ }^{2}$ Lisa Spoof, ${ }^{2}$ Urpo Lamminmäki ${ }^{1}$ \\ ${ }^{1}$ Molecular Biotechnology and Diagnostics, Department of Biochemistry, University of Turku, 20520 Turku; ${ }^{2}$ Biochemistry, Faculty of \\ Science and Engineering, Åbo Akademi University, FI-20520 Turku, Finland \\ *Corresponding author: sultana.akter@utu.fi
}

\begin{abstract}
Simple and cost-effective methods with sufficient sensitivities for preliminary screening of cyanobacterial toxins are in high demand for assessing water quality and safety. We have recently developed a highly sensitive and rapid time-resolved fluorometry based noncompetitive immunoassay for detection of microcystins and nodularins. The assay is based on a synthetic broad-specific anti-immunocomplex antibody SA51D1 capable of recognizing the immunocomplex formed by a generic anti-Adda monoclonal antibody (mAb) bound to either microcystins or nodularins. Using the same antibody pair, here we describe a very simple and cost-efficient non-competitive ELISA test for microcystins and nodularins based on conventional alkaline phosphatase (AP) activity measurement. The recombinant SA51D1 single-chain fragment of antibody variable domain ( $\mathrm{scFv}$ ) was produced as a fusion with bacterial alkaline phosphatase in Escherichia coli. After one step affinity purification through His-tag, the scFv-AP fusion protein could directly be used in the assay. For the assay, toxin standard/sample, biotinylated anti-Adda mAb and the scFv-AP were incubated together for one hour on streptavidin-coated microtiter wells, washed and AP activity was then measured by incubating $\left(1 \mathrm{~h}\right.$ at $\left.37^{\circ} \mathrm{C}\right)$ with chromogenic substrate para-nitrophenylphosphate (pNPP). The assay was capable of detecting all the eleven tested toxin variants (microcystin-LR, -dmLR, -RR, -dmRR, -YR, LA LY, -LF -LW, -WR, and nodularin-R) below WHO guide line value of $1 \mu \mathrm{g} \mathrm{L} \mathrm{L}^{-1}$. The detection limit (based on blank+3SD response) for microcystin-LR was $0.2 \mu \mathrm{g} \mathrm{L} \mathrm{L}^{-1}$. The assay was verified using spiked (0.25-4 $\mu \mathrm{g} \mathrm{L}^{-1}$ of microcystin-LR) tap, river and lake water samples with recoveries from 64 to $101 \%$. The assay showed good correlation $\left(\mathrm{r}^{2}>0.9\right)$ with four reference methods for its performance in detecting extracted intracellular microcystin/nodularin from 17 natural surface water samples. The described easy-to-perform assay has a high potential to be used in resource-poor settings as quantitative measurements can be obtained using a simple ELISA reader or easy-to-interpret qualitative results by visual readout. Based on the non-competitive format, the assay does not need any chemical toxin conjugates and offers robustness as compared to the currently available competitive format assays.
\end{abstract}

Key words: Immunocomplex assay; sandwich-type ELISA; cyanotoxin; microcystin; nodularin; harmful algal bloom.

Received: 17 October 2016. Accepted: 31 January 2017.

\section{INTRODUCTION}

Cyanobacterial blooms cause local and global problems by contaminating surface water resources with their diverse types of potent toxins commonly known as cyanobacterial toxins or cyanotoxins. The most frequently reported and widespread cyanotoxins are the cyclic heptapeptide microcystins (molecular weight $\sim 1000 \mathrm{Da}$ ) in fresh water and penta-peptide nodularins (molecular weight $825 \mathrm{Da}$ ) in brackish water. Microcystins and nodularins are potent hepatotoxins (liver toxins) with an acute LD50 value of 25 to $\sim 1000 \mu \mathrm{g} \mathrm{kg}^{-1}$ (mouse, i.p.) (Codd et al., 2005). Besides acute toxicity, microcystins and nodularins are tumor promoters (Nishiwaki-Matsushima et al., 1992; Sueoka et al., 1997) and microcystin-LR is described as a possible carcinogen (Grosse et al., 2006). Microcystins are mainly produced by the most common cyanobacteria genera found world-wide: Microcystis, Dolichospermum, Nostoc, Planktothrix, Anabaenopsis, and Hapalosiphon. The brackish water cyanobacterium Nodularia is the main producer of nodularins (Codd et al.,
2005). Overall occurrences of these toxins in surface water resources pose detrimental health threat to human and various animals including livestock, wild mammals and birds (Codd et al., 2005; Stewart et al., 2008; Merel et al., 2013). The World Health Organization guideline limit for microcystin-LR in drinking water is $1 \mu \mathrm{g} \mathrm{L}^{-1}$ (WHO, 2011).

Simple and efficient methods for cyanotoxin detection are in high demand in order to assess the quality of water sources used for drinking water abstraction and for recreational or agricultural use. However, the structural diversity of this toxin family constitutes a great challenge when monitoring water or making an assay. The unusual $\beta$-amino acid Adda (3-Amino-9-methoxy-2,6,8-trimethyl-10phenyldeca-4(E),6(E)-dienoic acid) (Botes et al., 1984; Rinehart et al., 1988) is common for both microcystins and nodularins; and has important role in toxicity (Dahlem, 1989). Other structural features necessary for the toxicity include the cyclic structure of the toxin (Choi et al., 1993; Rinehart et al., 1994) as well as the free carboxylic acid group in the D-Glu unit (Stotts et al., 1993). A change of 
two (microcystin) or one (nodularin) amino acid(s), together with several other structural modifications such as methylation, hydroxylation, and epimerization in small side groups during nonribosomal peptide synthesis creates diversity (Rinehart et al., 1994; Sivonen, 1996; Neilan et al., 1999).Variation has been observed in all positions of microcystins and nodularins; and close to 250 analogues of microcystin and 10 analogues of nodularin with differing toxicity have been reported to date in the literature (Sivonen and Jones, 1999; Mazur-Marzec et al., 2006; Puddick, 2013; Niedermeyer, 2014; Spoof and Catherine, 2017).

Different laboratory analysis methods exist for measuring microcystins and nodularins from water bodies and environmental samples. In general, immunoassays (commonly known as ELISA) or protein phosphatase inhibition assay (PPIA) are used for preliminary screening, followed by quantification and identification by sophisticated methods like high-performance liquid chromatography (HPLC) coupled to mass spectrometry (MS) for positive samples (Meriluoto and Codd, 2005; Lawton and Edwards, 2008). Immunoassay techniques are emerging popular methods due to their simplicity together with easiness to handle. Water samples (either tap water or from natural water bodies) can be analyzed as such with immunoassay techniques. Immunoassays are amenable for automation and screening of large number of samples and they can reduce the need for more expensive and time consuming analyses (Sivonen, 2008). Though the direct non-competitive immunoassay offers theoretical advantages (for example, in terms of sensitivity, high specificity, flexibility etc.) over the competitive format assays, all the currently available commercial immunoassay kits for microcystins/nodularins are in the competitive format. The main reason is that the molecular weight of cyanotoxin is about 1000 Daltons, making it difficult or even impossible to have two independent binding sites on its surface needed for non-competitive immunoassays. Non-competitive assays rely on direct measurement of antibody binding sites occupied by analyte producing an easy-to-interpret signal which is proportional to analyte concentration. On the other hand, competitive assays rely on measurement of unoccupied sites, from which the occupied sites are inferred by subtraction (Deshpande, 1996; Self et al., 2013). Due to the indirect approach the competitive assays usually require several assay steps and produce decreasing signal with increasing analyte concentration. As the signal in the absence of the analyte is already high, it is difficult to discern the slight changes in the signal caused by low analyte concentrations, especially with visual detection. Also, the competitive assays usually require strict maintaining of the reaction condition since equilibrium must be reached (Deshpande, 1996; Self et al., 2013).

We have recently reported isolation of a unique generic anti-immunocomplex binder from our in-house synthetic antibody library and development of a broad-spectrum non- competitive immunocomplex immunoassay for microcystins and nodularins (Akter et al., 2016). The described time-resolved fluorometry (TRF) based assay is highly sensitive and rapid. However, in addition to a lanthanide chelate (europium) labeled tracer reagent, the assay requires a fluorometer with TRF detection capability which is unfortunately rarely found in laboratories. In order to omit the need of special reagent and instrumentation, we describe here an ELISA method based on the aforementioned immunocomplex assay principle using particularly simple-toproduce components and easily accessible detection chemistry. The capability of the assay for broad-spectrum detection of microcystins and nodularins is demonstrated using purified toxins and environmental samples that were also tested with several reference methods.

\section{METHODS}

\section{Common materials and Instruments}

Common inorganic and organic chemical reagents were obtained from commercial source either from Sigma or Merck unless otherwise specified. The reagent water used was purified by Millipore Milli-Q Plus water filtration purification system (Millipore Corporation, Bedford, MA, USA). Multilabel counter Victor 1420 for signal measurement was from Wallac/PerkinElmer Life Sciences, (Waltham, MA, USA). Streptavidin coated microtiter plates were from Kaivogen Oy (Turku, Finland). Monoclonal antibody, AD4G2 (Adda specific, anti-Microcystins) was from Enzo Life Sciences, Inc. (Farmingdale, NY, USA) and was biotinylated with biotinisothiocyanat (BITC) to be captured on streptavidin surface of microtiter well. Assay buffer was composed of $50 \mathrm{mM}$ TSA (Tris saline azide buffer) $\mathrm{pH} 7.75$ supplemented with $0.01 \%$ Tween 40 , $0.05 \%$ Bovine- $\gamma$-globulin, $20 \mu \mathrm{M}$ DTPA (diethylenetriaminepentaacetic acid), $0.5 \%$ Bovine serum albumin (BSA) and finally (optional) $20 \mu \mathrm{g} \mathrm{mL}^{-1}$ of Amaranth dye solution (CAS: 915-67-3, Sigma) to aid pipetting. Wash buffer for washing of microtiter well-plate contained $5 \mathrm{mM}$ Tris- $\mathrm{HCl} \mathrm{pH} 7.75,0.9 \% \mathrm{NaCl}, 0.1 \%$ Germall II, and $0.005 \%$ Tween 20. The bacterial host Escherichia coli (E. coli) XL1-Blue was from Agilent Technologies (Santa Clara, CA, USA) and used for expression of the singlechain fragment of antibody variable domain (scFv). Paranitrophenyl phosphate (pNPP) substrate 4-Nitrophenyl phosphate disodium salt hexahydrate was from SigmaAldrich (St. Louis, MO, USA).

\section{Toxin standards}

Specific amount of the purified toxins (Supplementary Fig. 1) (microcystin-LR, -dmLR, -RR, -dmRR, -YR, -LA -LY, -LF -LW, and nodularin-R) were obtained from Dr. Meriluoto's Lab (Åbo Akademi University) as a 
lyophilized dried powder. The toxins were purified by preparative HPLC according to methods described earlier (Meriluoto and Codd, 2005). Microcystin-LA and microcystin-WR were purchased from Enzo Life Science. All the toxin standards were stored dry at $-20^{\circ} \mathrm{C}$ until required. Dry powder was dissolved in 50\% methanol (100$250 \mu \mathrm{g} \mathrm{mL}^{-1}$ original stock solution) and kept at $-20^{\circ} \mathrm{C}$ or $4^{\circ} \mathrm{C}$ in sealed condition. From these original stocks, further working solutions and standards were prepared in reagent water and stored at $-20^{\circ} \mathrm{C}$, or at $4^{\circ} \mathrm{C}$. The maximum percentage volume of methanol in the toxin standard solution $\left(0.02-600 \mu \mathrm{g} \mathrm{L}^{-1}\right)$ used in the assay was $0.3 \%$.

\section{Generic anti-immunocomplex binder for microcystin and nodularin}

The clone SA51D1scFv-AP (generic anti-immunocomplex binder for microcystin and nodularin) used in this study does not show detectable specificity to the naked antiAdda monoclonal antibody $(\mathrm{mAb})$ or to the toxin alone and is capable of recognizing the immunocomplexes composed of anti-Adda $\mathrm{mAb}$ bound to any of the eleven tested cyanotoxin analogues (Supplementary Fig. 1). The isolation and characterization of the binder antibody was described in detail earlier (Akter et al., 2016).

\section{Production and purification of scFv-AP fragments}

E. coli cells carrying the clone SA51D1 construct in pLK06H (Huovinen et al., 2013) vector were grown in 50 $\mathrm{mL}$ shaking flask in SB medium supplemented with 100 $\mu \mathrm{g} \mathrm{mL}^{-1}$ ampicillin, $10 \mu \mathrm{g} \mathrm{mL}^{-1}$ tetracycline and $0.05 \%$ glucose. The cells were induced with IPTG (isopropyl- $\beta$ D-1-thiogalactopyranoside induction) to the final concentration of $100 \mu \mathrm{M}$ and incubated overnight at $26^{\circ} \mathrm{C}$, with shaking at $300 \mathrm{rpm}$. Cells from the culture supernatant were used to purify the scFv-AP protein by His affinity column (His Spin Trap ${ }^{\mathrm{TM}}$ kit, GE Healthcare, UK) according to the manufacturer's instructions.

\section{Non-competitive ELISA}

One hundred $\mu \mathrm{L}$ per well of reagent water (for blank measurement, 6-56 replicates per assay), toxin standard solution (of concentration: $0.02-600 \mu \mathrm{gL}^{-1}$, prepared in reagent water), or samples were added in prewashed streptavidin wells (2-4 replicates for standard or sample). Then, $100 \mu \mathrm{L}$ per well of antibodies (biotinylated anti-Adda $\mathrm{mAb}$, $1 \mu \mathrm{g} \mathrm{mL}^{-1}$ and scFv-AP, $1 \mu \mathrm{g} \mathrm{mL}^{-1}$ ) prepared in assay buffer were added to each well. The wells were incubated (with slow shake) for $1 \mathrm{~h}$ at room temperature (RT, $\sim 23^{\circ} \mathrm{C}$ ) followed by four washes. Then pNPP liquid substrate solution (5 mM) prepared in $0.1 \mathrm{M}$ glycine buffer, $1 \mathrm{mM}$ $\mathrm{MgCl}_{2}, 1 \mathrm{mM} \mathrm{ZnCl}_{2}$, pH 10.4 was added $(200 \mu \mathrm{L}$ per well). Plates were incubated at $37^{\circ} \mathrm{C}$ for $1 \mathrm{~h}$ and absorbance was measured at $405 \mathrm{~nm}$. The assay concept and procedure is illustrated in Supplementary Fig. 2. Sample concentrations were calculated from the standard curve (microcystin-LR) using Origin 2015 software (OriginLab Corporation, Wellesley Hills, USA). The detection limit (the smallest detectable toxin concentration in sample) was calculated from the standard curve based on the average response of " $n$ " ( $n=6$ to 56) number of replicates of blank plus 3 times standard deviation of the blank.

\section{Influence of temperature and incubation time on assay performance}

The effect of temperature and incubation time on the assay performance during initial bioaffinity reaction and during the signal development stage (AP activity) was tested using microcystin-LR standard of concentration $0.02-600 \mu \mathrm{g} \mathrm{L}^{-1}$. The assay protocol was same as described above with following exception. The initial bioaffinity reaction was tested either at RT or at $37^{\circ} \mathrm{C}$ for $30 \mathrm{~min}$ and 1 h. After the washing step, pNPP liquid substrate was added and incubated either at RT or at $37^{\circ} \mathrm{C}$. The measurements were carried out at different time points ( $30 \mathrm{~min}$ to $24 \mathrm{~h}$ ).

\section{Non-competitive ELISA with different toxin variants}

The standard curves (toxin standard concentration: 0.02 to $600 \mu \mathrm{g} \mathrm{L}^{-1}$ ) of eleven microcystin/nodularin analogues (Supplementary Fig. 1) were obtained (duplicate measurements, for blank, $\mathrm{n}=56$ ) using the protocol described above. Signal development after washing step was done at $37^{\circ} \mathrm{C}$; absorbance was measured after $1 \mathrm{~h}$.

\section{Non-competitive ELISA with spiked water samples}

A total of four water samples including one reagent water, one tap water sample from our laboratory, one river water (Paimio River) and one lake water (Paalijärvi) samples from Finland were spiked with microcystin-LR at concentration from 0.25 to $4 \mu \mathrm{g} \mathrm{L}^{-1}$ (Tab.1). The environmental surface water samples were collected during 2009 (Tab. 2) and were stored as such at $-20^{\circ} \mathrm{C}$ until use. Upon thawing at RT, samples were spiked with microcystin-LR over a range of concentrations $(0,0.25$, $0.5,1,2$ and $\left.4 \mu \mathrm{g} \mathrm{L}^{-1}\right)$. The spiked samples and the corresponding unspiked samples were measured by the noncompetitive ELISA in duplicates. The unspiked samples were also measured by a commercial immunoassay (Microcystins-ADDA ELISA, Abraxis, PA, USA) and by the time resolved fluorescent measurement based non-competitive immunoassay (Akter et al., 2016). Presence of toxin in the unspiked samples by any of the three tested methods was taken into consideration for recovery calculation. The recovery percentage of the spiked sample was calculated as follows: $\mathrm{R} \%=$ (spiked sample result unspiked sample result) $X$ (known spike added concentration $)^{-1}$ X $100 \%$. 


\section{Non-competitive ELISA with surface environmental water samples}

A total of seventeen environmental surface water samples from a sample panel collected during 2009 from Finland and Estonia were tested using the non-competitive ELISA for internal (cellular) toxin in water. The samples constituted of cyanobacterial cells harvested on filters which were extracted for intracellular toxins with $75 \%$ methanol by method described earlier (Hautala et al., 2013; Savela et al., 2014). The methanolic extracts were aliquoted $(100-500 \mu \mathrm{L}$ extract) and the aliquots evaporated dry. The individual aliquots were re-dissolved in reagent water for PPIA and in $75 \%$ methanol for HPLC. The PPIA method was based on protein phosphatase 1 inhibition of p-nitrophenyl phosphate cleavage followed spectrophotometry (using microcystin-LR as reference) according to the method described earlier (Rapala et al., 2002; Rodríguez et al., 2008). The identification of microcystin/nodularin analogues and toxin amount (using microcystin-LR as reference) measurement by HPLC were carried out according to the method described earlier (Hautala et al., 2013). The liquid chromatography-mass spectrometry (LC-MS) and the commercial immunoassay results (QuantiPlate Kit for Microcystin, Envirologix, Portland, ME, USA) of these samples have been published earlier, where the commercial immunoassay was referred as ELISA (Savela et al.,
2014). From the 2009 sample panel, one additional set of aliquots (stored at $-20^{\circ} \mathrm{C}$ ) of seventeen samples were reconstituted in reagent water and analysed with the noncompetitive ELISA for measuring intracellular microcystin/nodularin amount. Suitable dilutions were prepared in reagent water based on the reference results to adjust the toxin concentration within the working range of the assay.

\section{RESULTS}

\section{Influence of temperature and incubation time on assay performance}

In the initial experiments the assay was performed at RT but due to relative long ( $2 \mathrm{~h}$ to overnight incubation) signal development phase, we explored the influence of the increased temperature on the assay performance. During initial bioaffinity step, temperature did not have significant effect on the assay performance; however, $1 \mathrm{~h}$ incubation provided $25 \%$ higher signal as compared to 30 min incubation.

Based on this ( $1 \mathrm{~h}$ initial bioaffinity step at RT), we then explored the influence of the increased temperature on the rate of the signal development (Fig. 1). After addition of pNPP liquid substrate, the reactions were incubated either at RT or at $37^{\circ} \mathrm{C}$. AP was shown to be more
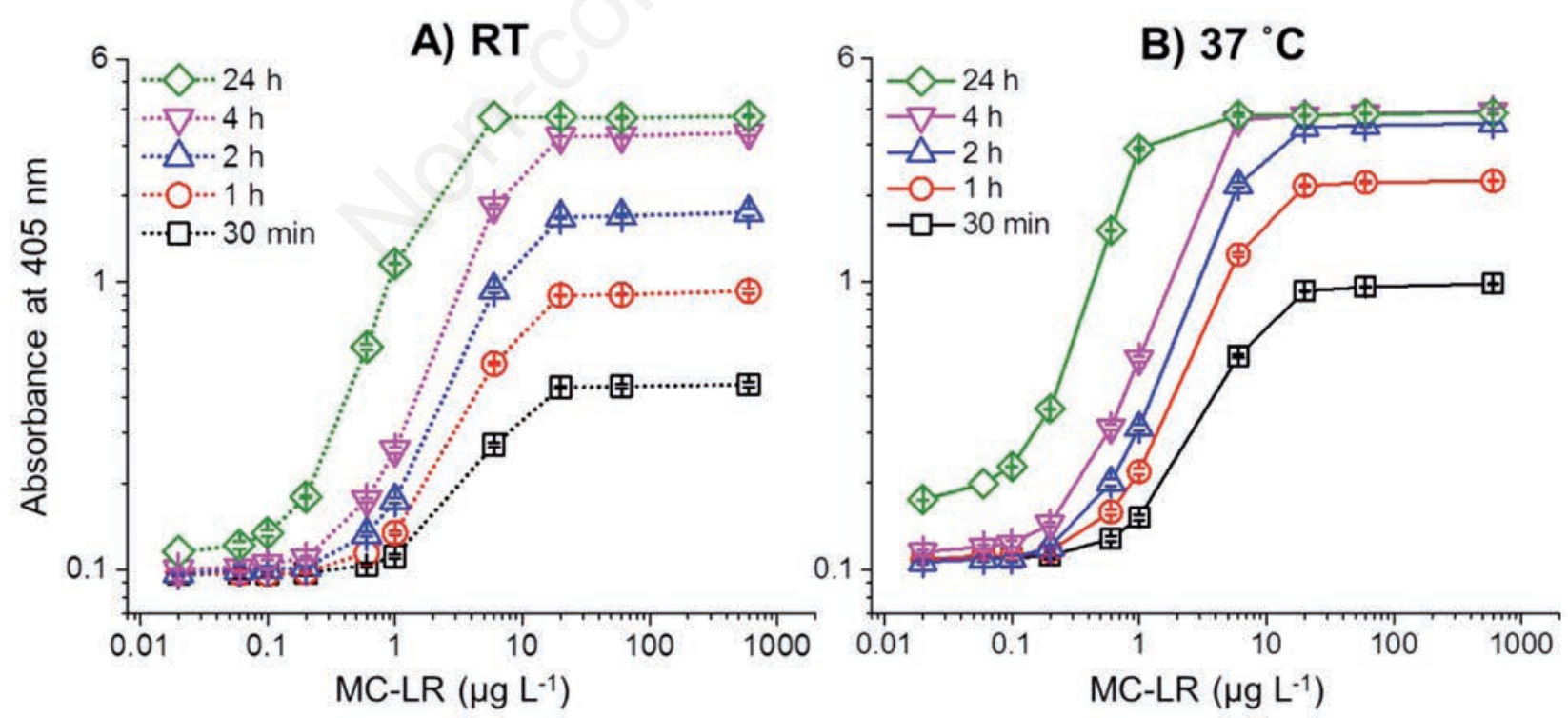

Fig. 1. Effect of temperature and incubation time for the AP activity in non-competitive ELISA using microcystin-LR as standard. The concentration ( $\mu \mathrm{g} \mathrm{L}^{-1}$ ) of microcystin-LR standard added in wells is plotted on X axis (logarithmic scale) while the corresponding absorbance at $405 \mathrm{~nm}$ resulting from AP activity at $\mathrm{RT}(\mathrm{A})$ or at $37^{\circ} \mathrm{C}(\mathrm{B})$ measured at different time points $(30 \mathrm{~min}$ to $24 \mathrm{~h})$ are plotted on $\mathrm{Y}$ axis (logarithmic scale). Each point represents average of two measurements. The standard errors of the means ( $\mathrm{n}=2)$ are shown as error bars. 
active at $37^{\circ} \mathrm{C}$. Within $30 \mathrm{~min}$ to $2 \mathrm{~h}$, the incubation at $37^{\circ} \mathrm{C}$ yielded at least two times higher specific signal (signal - blank) for microcystin-LR throughout the concentration range of $0.2-600 \mu \mathrm{g} \mathrm{L}^{-1}$ than that obtained at RT. The disadvantage of lower temperature could be compensated by prolonged incubation at RT. For example, colour development at RT with $1 \mathrm{~h}, 2-3 \mathrm{~h}$ and $4 \mathrm{~h}$ yielded similar level of signals as at $37^{\circ} \mathrm{C}$ using $30 \mathrm{~min}, 1 \mathrm{~h}$ and $2 \mathrm{~h}$ colour development time, respectively. Unlike at RT, an increase in the background signal was observed at $37^{\circ} \mathrm{C}$ along prolonged incubation (Fig. 1, Fig. 2).

\section{Performance of non-competitive ELISA with different toxin variants}

The assay was tested for its capacity to detect different microcystins and nodularin using 11 cyanotoxin congeners in a series of concentrations $\left(0.02\right.$ to $\left.600 \mu \mathrm{g} \mathrm{L}^{-1}\right)$. As indicated by the results (Fig. 2), all the tested cyanotoxin analogues could be detected below the WHO guideline limit of $1 \mu \mathrm{g} \mathrm{L}^{-1}$ in total of 2 hours assay time (one hour sample incubation at RT followed by one hour signal development at $37^{\circ} \mathrm{C}$ ). The detection limit (based on blank $+3 \mathrm{SD}, \mathrm{n}=56$ ) was below $0.6 \mu \mathrm{g} \mathrm{L}^{-1}$ for all the tested toxin variants and for microcystin-LR that value was $0.2 \mu \mathrm{g} \mathrm{L}^{-1}$. From standard curves the performance range of the assay was found to be from $0.6 \mu \mathrm{g} \mathrm{L}^{-1}$ to $20 \mu \mathrm{g} \mathrm{L}^{-1}$. The signals reached plateau level with standard concentration more than $20 \mu \mathrm{g}$

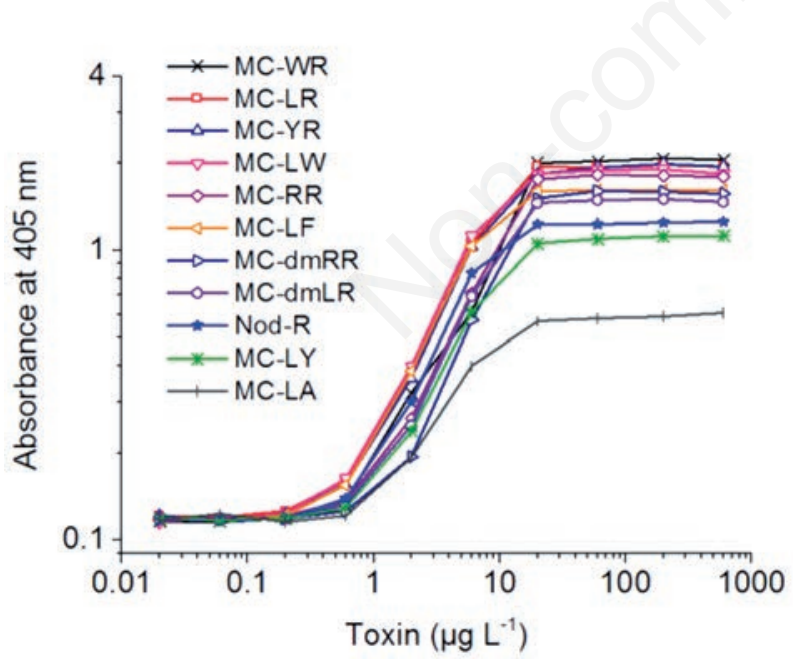

Fig. 2. The non-competitive ELISA standard curves for eleven different cyanobacterial toxin analogues in total $2 \mathrm{~h}$ assay. Each point is average of duplicate and standard errors of means are not shown for visual clarity. The concentrations $(0.02$ to $600 \mu \mathrm{g}$ $\mathrm{L}^{-1}$ ) of toxin standards added to wells are plotted in $\mathrm{X}$ axis (in logarithmic scale) while the corresponding signals (absorbance at $405 \mathrm{~nm}$ ) are plotted in $\mathrm{Y}$ axis in logarithmic scale. The detection limit (based on blank+3SD, $\mathrm{n}=56$ ) is below $0.6 \mu \mathrm{g} \mathrm{L}^{-1}$ for all the tested toxin analogues. MC, microcystin; Nod, nodularin.
$\mathrm{L}^{-1}$ and no high dose hook effect was observed within the assay with the highest standard toxin concentration of 600 $\mu \mathrm{g} \mathrm{L^{-1 }}$. Based on the specific signal levels at $6 \mu \mathrm{g} \mathrm{L}^{-1}$, the cross reactivity for the tested microcystin/nodularin analogues relative to microcystin-LR (100\%) ranged from 53\% (microcystin-LY and -WR) to 107\% (microcystin-LW), except for microcystin-LA (30\%).

\section{Visual interpretation of the assay result}

In order to assess the performance of the assay for its applicability in near water sources for qualitative results we observed and recorded the visual colour formation at RT and at $37^{\circ} \mathrm{C}$ from $30 \mathrm{~min}$ to $24 \mathrm{~h}$. In the presence of toxin, the scFv-AP becomes bound to the reaction well and then converts the colourless PNPP substrate into visually detectable yellow coloured end product (Supplementary Fig. 2). Fig. 3 shows the comparisons of colour formation
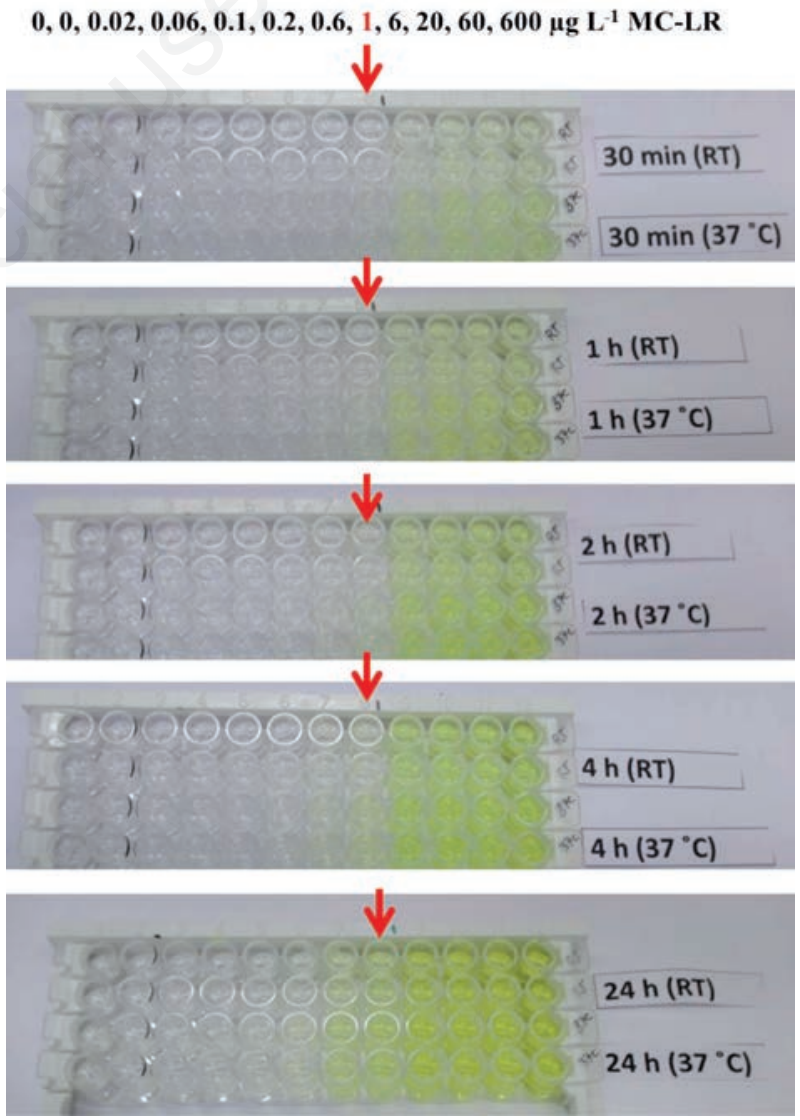

Fig. 3. Visually detectable colour formation for the non-competitive ELISA. Yellow visible colour was detected at RT and at $37^{\circ} \mathrm{C}$ in $30 \mathrm{~min}$ to $24 \mathrm{~h}$ time period using $0,0.02-600 \mu \mathrm{g} \mathrm{L}^{-1} \mathrm{mi}-$ crocystin-LR standard solution. The colour intensity increases with the increase of toxin concentration at a given time point. Colour development can be speeded up at higher temperature or through longer incubation. The arrows indicate the wells where $1 \mu \mathrm{g} \mathrm{L}^{-1}$ of microcystin-LR standard solution was added. 
at different times and temperatures. The WHO guideline value was visually detectable after $2 \mathrm{~h}$ colour formation at $37^{\circ} \mathrm{C}$ while 3-4 h incubation was required at RT.

\section{Performance of non-competitive ELISA with spiked water samples}

Four spiked water samples were used in the non-competitive ELISA directly (without any concentration or dilution steps) to measure the microcystin-LR concentration. The non-spiked controls were also measured. Tab.1 shows the measured concentration and the recovery percentage. The reagent water and the tap water samples were found to be free of detectable toxin while the river water was found to contain a low amount of toxin $\left(0.17 \mu \mathrm{g} \mathrm{L}^{-1}\right.$ to $0.21 \mu \mathrm{g}$ $\mathrm{L}^{-1}$ ) by all the three methods. The toxin content in the lake water was undetectable by the non-competitive ELISA and the commercial ELISA. However, it contained a low amount of toxin $\left(0.03 \mu \mathrm{g} \mathrm{L}^{-1}\right)$, as revealed by the TRF assay (Akter et al., 2016). The recovery values ranged from 64\% to $101 \%$ and the coefficient of variation \% (CV\%) values of the measurements were below 10.5 for the spiking concentrations of 0.5 to $4 \mu \mathrm{g} \mathrm{L}^{-1}$. In the case of the lowest spiking concentration $\left(0.25 \mu \mathrm{g} \mathrm{L}^{-1}\right)$, close to the assay's detection limit, the $\mathrm{CV} \%$ values were below 24.5.

\section{Performance of non-competitive ELISA with environmental samples}

Seventeen surface water samples (extracted intracellular toxin) were analysed by the non-competitive ELISA, PPIA and HPLC (Tab. 2). For these samples, commercial immunoassay and LC-MS results also were available (Savela et al., 2014). The toxin concentration detected by the four reference methods (commercial immunoassay, PPIA, HPLC and LC-MS) ranged from non-detectable to as high as $40.9 \mu \mathrm{g} \mathrm{L}^{-1}$ in the samples. From these, eleven samples were found to contain less than $1 \mu \mathrm{g} \mathrm{L}^{-1}$ of toxin and two samples were found to have more than $1 \mu \mathrm{g} \mathrm{L}^{-1}$ of toxin by all the four methods. The toxin content of these samples revealed by the non-competitive ELISA ranged from non-detectable to $39.1 \mu \mathrm{g} \mathrm{L}^{-1}$ and correlates well with the values obtained by the reference methods. Coefficients of determination $\left(\mathrm{r}^{2}\right)$ values ranged from 0.90 to 0.99 for the four reference methods.

\section{DISCUSSION}

Immunoassays provide an easy-to-access and affordable option for quantitative detection of specific compounds. Allowing reliable analysis outside well-equipped

Tab.1. Performance of non-competitive ELISA with spiked water sample.

\begin{tabular}{|c|c|c|c|c|c|}
\hline & $\begin{array}{l}\text { Origin of water sample } \\
\text { and date of collection }\end{array}$ & $\begin{array}{l}\text { Microcystin-LR } \\
\text { added to the sample } \\
\qquad\left(\mu \mathrm{g} \mathrm{L}^{-1}\right)\end{array}$ & $\begin{array}{c}\text { Microcystin-LR } \\
\text { determined by } \\
\text { non-competitive ELISA } \\
\left(\mu \mathrm{g} \mathrm{L}^{-1}\right)\end{array}$ & $\begin{array}{l}\text { CV of the } \\
\text { measurement } \\
(\%)\end{array}$ & $\begin{array}{c}\text { Recovery } \\
(\%)\end{array}$ \\
\hline 1 & Reagent water & $\begin{array}{c}0 \\
0.25 \\
0.5 \\
1 \\
2 \\
4\end{array}$ & $\begin{array}{l}- \\
0.22 \\
0.45 \\
0.96 \\
1.89 \\
3.68\end{array}$ & $\begin{array}{c}- \\
21.4 \\
3.3 \\
2.6 \\
2.2 \\
1.9\end{array}$ & $\begin{array}{l}- \\
87 \\
90 \\
96 \\
94 \\
92\end{array}$ \\
\hline 2 & $\begin{array}{l}\text { Drinking tap water } \\
03.07 .2016\end{array}$ & $\begin{array}{c}0 \\
0.25 \\
0.5 \\
1 \\
2 \\
4\end{array}$ & $\begin{array}{l}- \\
0.20 \\
0.40 \\
0.88 \\
1.87 \\
3.59\end{array}$ & $\begin{array}{c}- \\
24.4 \\
0.0 \\
1.8 \\
1.2 \\
1.5\end{array}$ & $\begin{array}{l}- \\
80 \\
81 \\
88 \\
93 \\
90\end{array}$ \\
\hline 3 & $\begin{array}{l}\text { Surface water } 1 \text { (river) } \\
\text { Paimio River, Palikainen, } \\
\text { Somero, Finland } \\
31.07 .2009\end{array}$ & $\begin{array}{c}0 \\
0.25 \\
0.5 \\
1 \\
2 \\
4\end{array}$ & $\begin{array}{l}0.21 \\
0.37 \\
0.60 \\
1.08 \\
2.06 \\
3.67\end{array}$ & $\begin{array}{c}5.6 \\
4.6 \\
1.1 \\
3.0 \\
0.7 \\
10.5\end{array}$ & $\begin{array}{c}- \\
64 \\
78 \\
87 \\
93 \\
86\end{array}$ \\
\hline 4 & $\begin{array}{l}\text { Surface water } 2 \text { (lake) } \\
\text { Paalijärvi, Riihimäki, Finland } \\
\text { 05.08.2009 }\end{array}$ & $\begin{array}{c}0^{*} \\
0.25 \\
0.5 \\
1 \\
2 \\
4\end{array}$ & $\begin{array}{c}- \\
0.23 \\
0.49 \\
1.04 \\
1.96 \\
3.84\end{array}$ & $\begin{array}{c}- \\
9.4 \\
2.9 \\
0.5 \\
1.5 \\
2.2\end{array}$ & $\begin{array}{c}- \\
82 \\
92 \\
101 \\
97 \\
95\end{array}$ \\
\hline
\end{tabular}

*Unspiked lake sample contained low amount of toxin $\left(0.03 \mu \mathrm{g} \mathrm{L}^{-1}\right)$ according to the TRF assay method (Akter $e$ al., 2016). 
Tab. 2. Intracellular microcystins/nodularins concentrations and toxin variants in environmental water samples from Finland and Estonia detected by non-competitive ELISA and four different reference methods.

\begin{tabular}{|c|c|c|c|c|c|c|c|}
\hline \multirow[t]{4}{*}{ Place and date } & \multirow{2}{*}{\multicolumn{5}{|c|}{$\begin{array}{l}\text { Concentration ( } \mu \mathrm{g} \mathrm{L}^{-1} \text { ) of microcystin/nodularin (intracellular) } \\
\text { in microcystin-LR equivalent }\end{array}$}} & \multirow{3}{*}{\multicolumn{2}{|c|}{$\begin{array}{l}\text { Observed } \\
\text { microcystin/nodularin } \\
\text { variant }\end{array}$}} \\
\hline & & & & & & & \\
\hline & \multirow{2}{*}{$\begin{array}{l}\text { Non-competitive } \\
\text { ELISA }\end{array}$} & \multirow[t]{2}{*}{ PPIA } & \multirow[t]{2}{*}{ HPLC } & \multirow{2}{*}{$\begin{array}{l}\text { Commercial } \\
\text { immunoassay }^{*}\end{array}$} & \multirow[t]{2}{*}{$\mathbf{L C}-\mathbf{M S}^{*}$} & & \\
\hline & & & & & & HPLC & $\mathbf{L C}-\mathbf{M S}^{\circ}$ \\
\hline $\begin{array}{l}\text { Lemböte byträsk, } \\
\text { Lemböte, Åland Islands, } \\
\text { Finland } \\
\text { 29.7.2009 }\end{array}$ & 0.40 & 0.17 & nd & 0.47 & 0.32 & & $\begin{array}{l}\text { MC-YR, } \\
\text { MC-dmLR }\end{array}$ \\
\hline $\begin{array}{l}\text { Hauninen reservoir, } \\
\text { Raisio, Finland } \\
\text { 14.7.2009 }\end{array}$ & 0.18 & 0.14 & 0.10 & 0.39 & 0.27 & MC-dmRR & MC-dmRR \\
\hline $\begin{array}{l}\text { Hauninen reservoir, } \\
\text { Raisio, Finland } \\
\text { 15.9.2009 }\end{array}$ & 0.65 & 0.26 & 0.13 & 1.14 & 0.86 & $\begin{array}{l}\text { MC-dmRR, } \\
\text { MC-LR }\end{array}$ & $\begin{array}{l}\text { MC-dmRR, } \\
\text { MC-RR, } \\
\text { MC-dmLR, } \\
1031,5\end{array}$ \\
\hline $\begin{array}{l}\text { Hauninen reservoir, } \\
\text { Raisio, Finland } \\
29.9 .2009\end{array}$ & 1.31 & 0.60 & 0.36 & 2.20 & 1.90 & & $\begin{array}{l}\text { MC-dmRR, } \\
\text { MC-dmLR, } \\
1031,5\end{array}$ \\
\hline $\begin{array}{l}\text { Hauninen reservoir, } \\
\text { Raisio, Finland } \\
29.10 .2009\end{array}$ & 0.58 & 0.20 & 0.14 & 1.20 & 0.68 & MC-dmRR & $\begin{array}{l}\text { MC-dmRR, } \\
\text { MC-dmLR, } \\
1031,5\end{array}$ \\
\hline $\begin{array}{l}\text { Paimio River }{ }^{c} \text {, Palikainen, } \\
\text { Somero, Finland } \\
\text { 31.7.2009 }\end{array}$ & nd & 0.11 & nd & 0.01 & nd & & \\
\hline $\begin{array}{l}\text { Savojärvi, } \\
\text { Pöytyä, Finland } \\
7.8 .2009\end{array}$ & 39.13 & 19.40 & 32.50 & 30.40 & 40.90 & $\begin{array}{l}\text { MC-dmRR, } \\
\text { MC-RR, } \\
\text { MC-dmLR, } \\
\text { MC-LR }\end{array}$ & $\begin{array}{l}\text { MC-didmRR, } \\
\text { MC-dmRR, } \\
\text { MC-didmLR, } \\
\text { MC-dmLR }\end{array}$ \\
\hline $\begin{array}{l}\text { Maaria reservoir, } \\
\text { Turku, Finland } \\
11.8 .2009\end{array}$ & 0.83 & 0.18 & 0.76 & 0.97 & 0.87 & $\begin{array}{l}\text { MC-RR, } \\
\text { MC-LR }\end{array}$ & $\begin{array}{l}\text { MC-dmRR, } \\
\text { MC-RR, } \\
\text { MC-YR, } \\
\text { MC-LR }\end{array}$ \\
\hline $\begin{array}{l}\text { Paalijärvi, }{ }^{\#} \\
\text { Riihimäki, Finland } \\
\text { 5.8.2009 }\end{array}$ & nd & nd & nd & 0.04 & nd & & \\
\hline $\begin{array}{l}\text { Tuusulanjärvi, } \\
\text { Tuusula, Finland } \\
\text { 16.9.2009 }\end{array}$ & nd & nd & nd & 0.04 & nd & & \\
\hline $\begin{array}{l}\text { Littoistenjärvi, } \\
\text { Kaarina, Finland } \\
\text { 26.6.2009 }\end{array}$ & nd & 0.08 & nd & 0.04 & 0.01 & & MC-dmRR \\
\hline $\begin{array}{l}\text { Littoistenjärvi, } \\
\text { Kaarina, Finland } \\
\text { 04.08.2009 }\end{array}$ & nd & 0.20 & nd & nd & nd & & \\
\hline $\begin{array}{l}\text { Littoistenjärvi, } \\
\text { Kaarina, Finland } \\
\text { 3.9.2013 }\end{array}$ & 0.66 & 0.40 & 0.20 & 0.76 & 0.50 & MC-RR & $\begin{array}{l}\text { MC-dmRR, } \\
\text { MC-RR, } \\
\text { MC-YR, } \\
\text { MC-dmLR, } \\
\text { MC-LR }\end{array}$ \\
\hline $\begin{array}{l}\text { Littoistenjärvi, } \\
\text { Kaarina, Finland } \\
\text { 11.9.2009 }\end{array}$ & 5.18 & 9.00 & 3.50 & 7.70 & 3.70 & $\begin{array}{l}\text { MC-dmRR, } \\
\text { MC-RR, } \\
\text { MC-LR }\end{array}$ & $\begin{array}{l}\text { MC-dmRR, } \\
\text { MC-RR, } \\
\text { MC-YR, } \\
\text { MC-dmLR, } \\
\text { MC-LR }\end{array}$ \\
\hline $\begin{array}{l}\text { Lake Peipus, } \\
\text { Rannapungerja beach, } \\
\text { Estonia } \\
25.8 .2009\end{array}$ & 0.73 & 0.24 & 1.10 & 0.55 & 0.60 & $\begin{array}{l}\text { MC-dmRR, } \\
\text { MC-RR, } \\
\text { MC-LR }\end{array}$ & $\begin{array}{l}\text { MC-dmRR, } \\
\text { MC-RR, } \\
\text { MC-YR, } \\
\text { MC-dmLR, } \\
\text { MC-LR }\end{array}$ \\
\hline $\begin{array}{l}\text { Lake Peipus, } \\
\text { Mustvee beach, } \\
\text { Estonia } \\
14.8 .2009\end{array}$ & 0.28 & 0.20 & nd & 0.29 & 0.20 & & $\begin{array}{l}\text { MC-dmRR, } \\
\text { MC-RR, } \\
\text { MC-dmLR, } \\
\text { MC-LR }\end{array}$ \\
\hline $\begin{array}{l}\text { Stroomi rand }(\mathrm{Sea}){ }^{\S} \\
\text { Estonia } \\
18.8 .2009\end{array}$ & 0.37 & 0.17 & 0.17 & 0.34 & 0.25 & Nod-R & $\begin{array}{l}\text { MC-dmRR, } \\
\text { Nod-R }\end{array}$ \\
\hline
\end{tabular}

${ }^{*}$ Commercial immunoassay [QuantiPlate Kit for Microcystin (Envirologix)] and the LC-MS results were published earlier (Savela $e t$ al., 2014$) ;{ }^{\circ}$ main toxin variants are highlighted in bold; ${ }^{*}$ corresponding raw water samples collected from these sources were used in spiking experiment; ${ }^{\S}$ commercial immunoassay, PPIA, HPLC and the LC-MS results for this sample was published earlier (Akter et al., 2016). MC, microcystin; Nod, nodularin; nd, not detected. 
high-level laboratories, immunoassays have been useful tools, for example, for environmental monitoring often performed close to the site of sampling. However, there are a number of different immunoassay configurations (Wild, 2013) varying significantly e.g., in terms of the complexity of the assay procedure and instrumentation needed, and thereby also in terms of the laboratory settings required. We have recently described a straightforward time-resolved fluorometry (TRF) based immunoassay for generic detection of cyanobacterial toxins, microcystins and nodularins (Akter et al., 2016). In the current study a similar broad-spectrum assay for microcystins/nodularins was established in a very easily accessible and affordable ELISA format facilitating the use of the assay also in resource poor settings by avoiding the need of the instrument required for TRF detection.

The capacity of the non-competitive ELISA for generic detection of microcystins and nodularins was demonstrated using eleven commonly occurring cyanotoxin analogues (microcystin-LR, -dmLR, -RR, -dmRR, -YR, LA -LY, -LF -LW, -WR, and nodularin-R). The detection limit (based on blank+3SD response) for all tested toxin analogues fell below $0.6 \mu \mathrm{g} \mathrm{L}^{-1}$ readily meeting the WHO guideline value of drinking water $\left(1 \mu \mathrm{g} \mathrm{L}^{-1}\right)$. The tested toxin analogues represent well the chemical diversity found in microcystins. For instance, both large and small as well as both polar or nonpolar amino acids can be found in the typical diversity displaying positions among the tested analogues. The fact that all these microcystin analogues, and also a penta-peptide nodularin analogue could be measured suggests that the assay is able to detect many other naturally occurring cyanotoxin analogues.

We analysed the capability of the non-competitive ELISA to detect the toxins in water samples using both spiked and real environmental specimens. As indicated by the acceptable recoveries obtained using raw surface water spiked with toxin (microcystin-LR) in concentrations $\left(0.25-4 \mu \mathrm{g} \mathrm{L}^{-1}\right)$ close to the WHO guideline value for drinking water, the assay can be readily applied for the analysis of both drinking and environmental surface water. The non-competitive ELISA was also tested for its capacity to detect intracellular microcystin/nodularin content from 17 extracted lyophilized samples originating from different natural surface water sources. Based on HPLC and LC-MS, the predominant toxin variants in these samples were microcystin-RR and -dmRR. Other detected toxin analogues included microcystin-LR, dmLR, -YR, -didmRR and nodularin-R. Very good correlations with the reference methods, PPIA, commercial immunoassay, HPLC and LC-MS were observed (coefficients of determination, $r^{2}>0.90$ ) indicating the practical applicability of the assay for samples having different microcystin analogues and nodularin.

The performance of the assay is not only affected by the duration of the bacterial alkaline phosphatase catalyzed signal development step, but also the temperature during the enzymatic reaction. Microcystin-LR could be detected below WHO guideline value using $30 \mathrm{~min}$ incubation at RT; however, to guarantee that all the tested toxin analogues were detected with this sensitivity $2 \mathrm{~h}$ incubation was required (data not shown). The detection limit could be pushed further down by extending the incubation time; after overnight incubation at RT the detection limit falls below $0.25 \mu \mathrm{g} \mathrm{L}^{-1}$ for all the tested variants. The enzyme catalyzed dephosphorylation of pNPP substrate can be significantly accelerated by increasing temperature; with $1 \mathrm{~h}$ incubation at $37^{\circ} \mathrm{C}$ all the tested variants were detectable below $0.6 \mu \mathrm{g} \mathrm{L}^{-1}$. Nevertheless, prolonged colour formation at RT yields similar or even somewhat improved sensitivity due to nearly constant background signal. An additional advantage of incubating at RT is that instruments with temperature control are not needed.

Compared to the previously reported TRF assay (Akter et al., 2016), the ELISA based assay shows somewhat lower sensitivity $\left(\sim 0.1 \mu \mathrm{g} \mathrm{L}^{-1}\right.$ of microcystin-LR $v s \sim 0.2$ $\mu \mathrm{g} \mathrm{L}^{-1}$ of microcystin-LR) and is more time consuming (10 $\min v s 2 \mathrm{~h}$ ). On the other hand, the ELISA test is very easy to perform and can be read with a simple ELISA reader also available as portable versions, or even by naked eye if qualitative read-out is sufficient. In addition, the described ELISA is economical, not only due to the inexpensive detection instrument, but also for the exceptionally affordable assay components. While the capture Adda specific monoclonal antibody was obtained from commercial sources, the secondary, anti-immunocomplex, antibody was produced in a simple bacterial expression culture as a ready-made conjugate with the enzymatic label. A milligram amount of the scFv-AP protein, sufficient for thousands of assay reactions can be isolated from a $50-\mathrm{mL}$ culture of $E$. coli by a single His-tag based affinity purification step. Moreover, the immunocomplex formation based assay concept allows by-passing the production of a labeled conjugate of the analyte. This often cumbersome process is essential for competitive assays which are typically used for the detection of low-molecular-weight compounds including the cyanobacterial toxins. An additional benefit of the assay, obtained irrespective of the detection system used, is the lack of high dose hook effect. As the anti-immunocomplex binder recognize neither the free toxin nor the naked anti-Adda antibody, excess of antigen does not lead to the collapse of the signal unlike in a conventional one-step (i.e., sample and tracer in the same incubation) sandwich immunoassay (Davies, 2013; Park and Kricka, 2013). Owing to this attribute, possible high dose samples cannot be misinterpreted as false negative result and only a single dilution of the sample needs to be tested during the initial screening. When quantitative results are needed, only the samples which give very high signal beyond the working range of 
the assay need to be retested with two to three more dilutions saving time and overall cost.

The non-competitive ELISA concept could potentially be applied to the development of simple detection tools for various other cyanobacterial or algal toxins. The limiting factor, however, is the availability of a suitable pair of binders encompassing a primary capture (not a polyclonal) and a recombinant anti-immunocomplex antibody. If a well-performing capture antibody for a toxin exists, a recombinant antibody library can be explored e.g., by phage display to obtain the anti-immunocomplex binder (Akter et al., 2016).

\section{CONCLUSIONS}

We have here demonstrated a recombinant anti-immunocomplex antibody based non-competitive ELISA for generic detection of microcystins and nodularins. The assay, validated against reference methods, is easy-to-use, robust and cost-effective, and it readily meets the WHO guideline level for drinking water. We believe that the assay, which can be performed with relatively simple instruments, or even qualitatively interpreted by naked eye, is wellsuited for use in water analysis laboratories, especially in the resource poor settings and at sampling location.

\section{ACKNOWLEDGMENTS}

This work has been financially supported (grant $823 / 31 / 2014$ ) by the National Technology Agency of Finland (TEKES). Sultana Akter received personal research grants from MVTT, Maa- ja vesitekniikan tuki (grant 24808) and from Turku University Foundation (grant 10146). SA, MV and UL are inventors in a pending patent application PCT/FI2016/050911 concerning the anti-immunocomplex antibody described in the manuscript. The assignee of the application is the University of Turku.

The authors would like to acknowledge the European Cooperation in Science and Technology, COST Action ES 1105 "CYANOCOST- Cyanobacterial blooms and toxins in water resources: Occurrence, impacts and management" for adding value to this study through networking and knowledge sharing with European experts and researchers in the field.

We are grateful to those colleagues who provided samples: Sonja Nybom (Åbo Akademi University), Pirkko Ala-Uotila (Raisio-Naantali Waterworks), Pirkko Pajakko (Turku Municipal Water Company), Marko Järvinen (Finnish Environment Institute), Kirsti Lahti (Water Protection Association of the River Vantaa and Helsinki Region) and Aune Annus and coworkers (Tervisekaitse, Estonia).

\section{REFERENCES}

Akter S, Vehniäinen M, Spoof L, Nybom S, Meriluoto J, Lamminmäki U, 2016. Broad-Spectrum noncompetitive immunocomplex immunoassay for cyanobacterial ceptide hepatotoxins (microcystins and nodularins). Anal. Chem. 88:10080-10087.

Botes DP, Tuinman AA, Wessels PL, Viljoen CC, Kruger H, Williams DH, Santikarn S, Smith RJ, Hammond SJ, 1984. The structure of Cyanoginosin-LA, a cyclic heptapeptide toxin from the cyanobacterium Microcystis-aeruginosa. J. Chem. Soc. Perkin Trans. 1:2311-2318.

Choi BW, Namikoshi M, Sun F, Rinehart KL, Carmichael WW, Kaup AM, Evans WR, Beasley VR, 1993. Isolation of linear peptides related to the hepatotoxins nodularin and microcystins. Tetrahedron Lett. 34:7881-7884.

Codd GA, Morrison LF, Metcalf JS, 2005. Cyanobacterial toxins: risk management for health protection. Toxicol. Appl. Pharmacol. 203:264-272.

Dahlem AM, 1989. Structure/toxicity relationships and fate of low molecular weight peptide toxins from cyanobacteria. $\mathrm{PhD}$ thesis, University of Illinois, Urbana-Champaign.

Davies C, 2013. Principles of competitive and immunometric assays (including ELISA), p. 29-59. In: D. Wild (ed.), The Immunoassay Handbook, 4th ed. Elsevier.

Deshpande SS, 1996. Enzyme immunoassays: From concept to product development. Springer, New York: $464 \mathrm{pp}$.

Grosse Y, Baan R, Straif K, Secretan B, El Ghissassi F, Cogliano V, 2006. Carcinogenicity of nitrate, nitrite, and cyanobacterial peptide toxins. Lancet Oncol. 7:628-629.

Hautala H, Lamminmaki U, Spoof L, Nybom S, Meriluoto J, Vehniainen M, 2013. Quantitative PCR detection and improved sample preparation of microcystin-producing Anabaena, Microcystis and Planktothrix. Ecotoxicol. Environ. Saf. 87:49-56.

Huovinen T, Syrjanpaa M, Sanmark H, Brockmann EC, Azhayev A, Wang Q, Vehniainen M, Lamminmaki U, 2013. Two ScFv antibody libraries derived from identical VL-VH framework with different binding site designs display distinct binding profiles. Protein Eng. Des. Sel. 26:683-693.

Lawton LA, Edwards C, 2008. Conventional laboratory methods for cyanotoxins. Adv. Exp. Med. Biol. 619:513-537.

Mazur-Marzec H, Meriluoto J, Plinski M, Szafranek J, 2006. Characterization of nodularin variants in Nodularia spumigena from the Baltic Sea using liquid chromatography/mass spectrometry/mass spectrometry. Rapid Commun. Mass Spectrom. 20:2023-2032.

Merel S, Walker D, Chicana R, Snyder S, Baures E, Thomas O, 2013. State of knowledge and concerns on cyanobacterial blooms and cyanotoxins. Environ. Int. 59:303-327.

Meriluoto J, Codd GA, 2005. TOXIC: cyanobacterial monitoring and cyanotoxin analysis. Åbo Akademi University Press, Åbo: 149 pp.

Neilan BA, Dittmann E, Rouhiainen L, Bass RA, Schaub V, Sivonen K, Borner T, 1999. Nonribosomal peptide synthesis and toxigenicity of cyanobacteria. J. Bacteriol. 181:4089-4097.

Niedermeyer T, 2014. Microcystin congeners described in the literature. figshare. http://dx.doi.org/10.6084/m9.figshare. 880756

Nishiwaki-Matsushima R, Ohta T, Nishiwaki S, Suganuma M, Ko- 
hyama K, Ishikawa T, Carmichael WW, Fujiki H, 1992. Liver tumor promotion by the cyanobacterial cyclic peptide toxin microcystin-LR. J. Cancer Res. Clin. Oncol. 118:420-424.

Park JY, Kricka LJ, 2013. Interferences in immunoassay, p. 403416. In: D. Wild (ed.), The immunoassay handbook, 4th ed. Elsevier.

Puddick J, 2013. Spectroscopic investigations of oligopeptides from aquatic cyanobacteria: Characterisation of new oligopeptides, development of microcystin quantification tools and investigations into microcystin production. $\mathrm{PhD}$ thesis, University of Waikato, New Zealand.

Rapala J, Erkomaa K, Kukkonen J, Sivonen K, Lahti K, 2002. Detection of microcystins with protein phosphatase inhibition assay, high-performance liquid chromatography-UV detection and enzyme-linked immunosorbent assay: Comparison of methods. Anal. Chim. Acta 466:213-231.

Rinehart K, Namikoshi M, Choi B, 1994. Structure and biosynthesis of toxins from blue-green algae (cyanobacteria). J Appl. Phycol. 6:159-176.

Rinehart KL, Harada K, Namikoshi M, Chen C, Harvis CA, Munro MHG, Blunt JW, Mulligan PE, Beasley VR, Dahlem AM, Carmichael WW, 1988. Nodularin, microcystin, and the configuration of Adda. J. Am. Chem. Soc. 110:8557-8558.

Rodríguez EM, Acero JL, Spoof L, Meriluoto J, 2008. Oxidation of MC-LR and -RR with chlorine and potassium permanganate: Toxicity of the reaction products. Water Res. 42:17441752.

Savela H, Vehniäinen M, Spoof L, Nybom S, Meriluoto J, Lamminmäki U, 2014. Rapid quantification of mcyB copy numbers on dry chemistry PCR chips and predictability of microcystin concentrations in freshwater environments. Harmful Algae 39:280-286.

Self CH, Thompson S, Street T, Lamb KJ, Duffin G, Dessi JL,
Turnbull M, 2013. Non-competitive immunoassays for small molecules-the anti-complex and selective antibody systems, p. 61-65. In: D. Wild (ed.), The immunoassay handbook, 4th ed. Elsevier.

Sivonen K, 1996. Cyanobacterial toxins and toxin production. Phycologia 35:12-24.

Sivonen K, 2008. Emerging high throughput analyses of cyanobacterial toxins and toxic cyanobacteria. Adv. Exp. Med. Biol. 619:539-557.

Sivonen K, Jones G, 1999. Cyanobacterial toxins, p. 41-111. In: I. Chorus and J. Bartram (eds.), Toxic cyanobacteria in water: a guide to their public health consequences, monitoring and management. Taylor \& Francis.

Spoof L, Catherine A, 2017. Appendix 3. Tables of microcystins and nodularins, p. 526-537. In: J. Meriluoto, L. Spoof, G. Codd (eds.), Handbook of cyanobacterial monitoring and cyanotoxin analysis. J. Wiley \& Sons.

Stewart I, Seawright AA, Shaw GR, 2008. Cyanobacterial poisoning in livestock, wild mammals and birds-an overview. Adv. Exp. Med. Biol. 619:613-637.

Stotts RR, Namikoshi M, Haschek WM, Rinehart KL, Carmichael WW, Dahlem AM, Beasley VR, 1993. Structural modifications imparting reduced toxicity in microcystins from Microcystis spp. Toxicon 31:783-789.

Sueoka E, Sueoka N, Okabe S, Kozu T, Komori A, Ohta T, Suganuma M, Kim SJ, Lim IK, Fujiki H, 1997. Expression of the tumor necrosis factor $\alpha$ gene and early response genes by nodularin, a liver tumor promoter, in primary cultured rat hepatocytes. J. Cancer Res. Clin. Oncol. 123:413-419.

WHO, 2011. Guidelines for drinking water quality, 4th ed. WHO, Geneva: 564 pp.

Wild D, 2013. Immunoassay for beginners, p. 7-10. In: D. Wild (ed.), The immunoassay handbook, 4th ed. Elsevier. 